\title{
한국 중고령자의 노인교육이 노후준비에 미치는 영향 \\ Effects of Recognition of Elderly Education on Provision for Old Age among Middle-Aged and Aged People in Korea
}

\author{
홍석태, 양해술 \\ 호서대학교 벤처전문대학원 정보경영학과
}

Seok-Tae Hong(kyungnodang@naver.com), Hae-Sool Yang(hsyang@office.hoseo.hoseo.ac.kr)

\section{요약}

본 연구는 중고령자를 대상으로 휴(休)상태에 있거나 퇴직이후를 위한 노인준비교육이 노인의 생활에 미칠 영향과 교육프로그램에 대한 자료를 얻고자함이 본연구의 목적이다. 실증 연구를 통하여 다음과 같 은 연구결과를 얻었다.

첫째, 노인교육의 필요성 인식과 노인교육 참여 욕구가 노후준비에 영향을 미치는 것으로 나타났다. 둘 째, 퇴직기대 유형의 새로운 출발, 경력완성, 계속기대가 노후준비에 영향을 미치는 것으로 나타났다. 셋 째, 노인교육의 필요성 인식은 노후의 신체적 준비, 심리적 준비, 경제적 준비에 퇴직기대가 부분적인 매개 효과를 보였고, 노인교육의 참여욕구는 퇴직기대가 노후의 신체적 준비에 완전매개효과를 가져왔으며, 퇴 직기대가 노후의 심리적 준비, 경제적 준비에 는 부분적인 매개효과를 보였다. 넷째, 인구통계학적인 특성 으로는 노인교육의 필요성 인식과 교육 참여욕구, 퇴직기대, 노후준비의 인식이 성별, 연령, 직업, 학력에 따라 통계적으로 유의미한 결과를 제시하고 있는 것으로 나타났다.

중심어 : | 노인교육의 필요성 인식 | 노인교육의 참여욕구 | 퇴직기대 | 노후준비 |

\section{Abstract}

The purpose of this study is to analyze the statistical data to get the government to have positive recognition of education for middle-aged and aged people about provision for old age after retirement and present a model of policy direction of realistic elderly education for middle-aged and aged people and an ideal program for middle-aged and aged people in Korea.

Such an empirical research obtained the following results.

First, as for effects of recognition of the need of elderly education and the desire to participate in elderly education on provision for retirement, the need of elderly education and the desire to participate in elderly education were found to have effects. Second, as for effects of the level of retirement expectation on provision for retirement, new departure, career completion, and continuous expectation were found to have effects. Third, as for mediating effects of retirement expectation in terms of effects of recognition of the need of elderly education and the level of desire for participation, the need of elderly education has retirement expectation partly affect physical, psychological, and economic preparation. As for the desire to participate in elderly education, expectation of retirement had completely mediating effects on physical preparation and partly mediating effects on psychological and economic preparation. Fourth, the need of elderly education, the desire for participation, retirement expectation, and recognition of provision for retirement by general properties were found to have statistically significant results in terms of gender, age, occupation, and educational background.

- keyword : | Recognition of Need of Elderly Education | Desire for Participation | Provision for Retirement | Retirement Expectation I

접수번호 : \#080424-001

접수일자 : 2008년 04월 24일
심사완료일 : 2008년 05월 14일

교신저자 : 홍석태, e-mail : kyungnodang@naver.com 


\section{I. 서 론}

2020년대의 한국사회는 65 세의 노인인구가 국민전체 인구의 $20 \%$ 이상을 넘어 초고령사회(super-aged Society)로 돌입하게 되면서 미래의 노인문제가 심각한 지경에 이를 것으로 통계청에서는 예측을 하고 있다 [10]. 다시 말해서 15 년 후에는 지금의 50 세가 65 세의 노인반열에 합류를 하게 되고 동시에, 평균 55 세를 기 준으로 퇴직을 하고 휴(休)를 맞이하는 장년의 유휴노 동력(遊休勞動力)이 많은 현실을 감안한다면 15년을 기 달릴 것도 없이 2008년 현재도 이미 국민인구의 $20 \%$ 이 상이 휴의 상태로 국가의 인적자원에 막대한 손실이 발 생을 하고 있다고 하겠다. 그러나 그들이 일정한 교육 의 기회를 통하여 스스로의 값진 생을 산다면 국가는 그들을 통하여 새로운 에너지를 얻게 될 것이라는 확신 을 가지며 교육을 통하여 무기력한 노인의 무(無)에서 사회에 일원으로 참여하면서 유(有)를 창출할 수 있다 고 믿고 본 연구를 시작하였다.

본 연구에서는 특히 50 대가 미래의 우리사회에 불어 닥칠 초고령사회의 실제 노인세대라는 점을 감안하여 55 세 전후를 설문의 대상으로 하였다. 그들은 질 높은 노인교육을 통하여 사회와 격리된 고독한 노인이 아니 라 개인적으로는 삶의 만족과 행복을 구사하고 사회에 참여하여 새로운 분야에서 혹은 젊은이에게 외면당하 는 사각지대에서 행복한 마음으로 활동하는 새로운 노 인 상으로 존재하기를 바라는 기대가 본 연구를 하게 된 또 다른 목적이다. 이를 달성하기 위해서는 지금의 노인교육으로는 안되고 지금 부터라도 중고령자들에게 는 질이 높은 대학의 문을 개방하여 그들의 자신에게 맞는 평생교육을 저렴한 가격으로 문호를 개방하는데 국가의 적극적인 협조가 요구된다 하겠다. 연구조사 방 법에는 문헌연구로 기존의 연구 및 문헌들의 자료를 수 집하고 참고하여 미래의 노인 상을 정립하였고 실증연 구로는 분석대상을 노인복지 회관을 출입하는 노인과 중고령 직장인 그리고 중년가정주부를 대상으로 하였 으며 이들의 노인교육의 필요성과 교육의 참여욕구와 퇴직기대의 여러 상황이 노후준비에 미치는 관계를 살 펴보고, 인구통계학적인 특성이 퇴직기대의 매개위치
에 따라 노후준비에 미치는 영향을 비교분석하였다. 이 를 통하여 중고령자 및 퇴직자를 위한 노인준비교육에 정부의 긍정적인 인식을 위한 통계자료와 분석결과를 가지고 우리 실정에 맞는 중고령자에 합당한 노인 교육 의 정책방향과 그들을 위한 이상적인 프로그램의 기초 를 제시하고자 하였다.

\section{II. 이론적 배경}

\section{1. 한국인구의 변화 추이와 중고령자의 노인 교육 의 필요성}

\section{1 한국인구의 변화추이}

한국에 현재 평균수명의 연장과 함께 노인인구가 증 가하는 추세에 있다. [표 1] 에 나타난 바와 같이 1960년 에는 65 세 이상의 노인인구가 전체인구의 $2.9 \%$ 정도였 으나 2000년에는 $7.2 \%$ 로 증가하여 고령화 사회로 진입 하였다. 2005년 현재 노인인구는 전체인구의 $9.1 \%$ 에 도 달하였고, 2018년에는 $14.3 \%$ 로서 고령사회, 그리고 2026년에는 노인인구가 $20.8 \%$ 를 초월하여 초고령사회 (Super-Aged Society)로 들어갈 것으로 예상된다 [10].

2020년에는 $15.6 \%$ 로 65 세 이상의 노인인구가 770 만 명에 이르고, 65 세 이상의 노인의 인구가 14 세 이하의 아동 숫자보다 많은 시대가 곧 도래한다. 지금의 52 세 (중고령자)가 65세의 노인이 되는 2020년까지는 불과 12 년 밖에 남지 않았다.

\section{1 중고령자의 노인교육의 필요성}

(1) 현재 한국의 평균수명은 남자는 75세 여자는 82 세이다. 머지않아 평균수명이 90 세가 되는 시대가 곧 도래한다[5]. 이러한 시대에 50세 전후의 중고령자는 60 세 이후의 노인의 삶으로서 짧게는 15 년, 길게는 30 년 은 더 살아야한다. 이러한 제 3 의 인생을 위해서 교육을 통한 준비는 빠르게 변하는 시대에서 필수조건이라 하 겠다.

(2) 이들의 중고령자는 현재의 노인들과 비교할 때 경제력과 교육 수준이 높은 노인의 인구가 크게 증가할 
표 1. 1960 2050 년까지의 장래인구 추이

단위 : 천명, \%

\begin{tabular}{|c|c|c|c|c|c|c|}
\hline 연도 내용 & 총인구 & 0 14세(\%) & 15 64세(\%) & 65세 이상(\%) & 노인부양 지수 & 고령자 지수 \\
\hline 1960 & 25,012 & $10,588(42.3)$ & $14.258(57.0)$ & $726(2.9)$ & 5.1 & 5.9 \\
\hline 2000 & 47,008 & $9,911(21,1)$ & $33,702(71,7)$ & $3,395(7,2)$ & 10,1 & 34,3 \\
\hline 2005 & 48,294 & $9,240(19,1)$ & $34,671(71,8)$ & $4,383(9,1)$ & 12,6 & 47,4 \\
\hline 2010 & 49,220 & $8,013(16,3)$ & $35,852(72,8)$ & $5,354(10,9)$ & 14,9 & 66,8 \\
\hline 2018 & 49,934 & $6,495(13,0)$ & $36,276(72.6)$ & $7,162(14,3)$ & 19,0 & 110,3 \\
\hline 2026 & 49,771 & $5,796(12,8)$ & $33,618(67,5)$ & $10,357(20,8)$ & 30,8 & 178,7 \\
\hline 2050 & 42,348 & $3,799(9,0)$ & $22,755(53,7)$ & $15,793(37,3)$ & 69,4 & 415,7 \\
\hline
\end{tabular}

자료 : 통계청(2005) 장례인구추계 (김오차, 2006 : 11)

것이며, 조기퇴직이나 명예퇴직 등으로 인한 중고령자 의 수가 증가할 것으로 전망한다. 이러한 노인의 질적 변화와 함께, 저 출산 현상으로 경제활동인구가 감소하 고 노인인구의 상대적 증가로 인하여 노인 부양부담이 더욱 증가하면서 앞으로의 노인문제는 노인 스스로가 해결하고 모든 생활을 능동적으로 대처할 수 있는 중고 령자에게 질 높은 노인 준비 교육을 위해 국가의 인식 과 행정적인 지원이 요구된다.

\section{2. 한국 노인교육정책}

현재 우리의 노인교육정책은 평생 교육적 차원과 노 인복지차원의 한 부분으로 논의되어지고 있다. 「평생 교육법」에서 역시 노인교육에 관해서는 직접적이고 구체적인 사항이 없다. 평생교육법상에서 사용하는 '평 생교육'의 개념이 학교 외 청소년들이나 성인들의 교육 에 대한 사항으로 한정되고 있음을 볼 때 다만 노인교 육이 가볍게 평생교육의 범주 속으로 들어간다고 유추 하여 생각할 수 있을 뿐이다[1].

이와 같이 한국노인교육 정책의 특징을 분류한다면, 첫째, 노인교육의 실효성을 보장할 만한 구체적인 조항 이 법제화되어 있지 않다는 것이고, 둘째는, 노인교육을 전담할 행정체제가 보건복지부와 교육인적자원부, 노 동부 등으로 다원화 되어있다. 현재 정부 내에서는 국 가차원에서의 노인교육정책에 대한 인식이 부족하므로 노인교육을 전체적으로 통합 관리하는 주무부서의 중 요성을 인식하지 못하고 있다. 현재는 교육인적자원부 와 보건복지부, 부분적으로는 노동부 등 여러 부서에서 나누어 관리하기 때문에 노인교육의 목적과 교과과정
의 방향 설정, 노인교육기관 운영자와 강사의 육성과 재교육, 교재개발 등 국가적 차원에서의 효율적인 노인 교육관리와 지도 등이 소홀 한 편이다. 더욱이 사회교 육법과 동 시행령 등에서 나타나고 있는 노인교육정책 은 현재 노인학교의 여러 가지 문제점들을 해결하기에 는 미흡한 실정인 교실을 운영하고 있다[13]. 이것이 교 육인적자원부의 평생교육법과 보건복지부의 노인복지 법에 의한 노인교육의 이원화는 높은 질의 노인교육프 로그램 시행에 차질이 발생하므로 관련부처 및 기관과 의 협력이나 정책의 일원화가 필요한 시점이다. 미국의 경우는 연방정부산하에 노인청에서 관장함으로서 정책 과 예산의 일원화를 시킬 수 있다.

\section{3. 중고령자에 필요한 노인 교육 프로그램과 한국 의 현실}

\section{1 은퇴준비 교육 프로그램}

(1) 은퇴준비교육은 흔히 은퇴 전 교육(preretirement education)이라 하여 용어상의 의미로는 은 퇴 전에 따른 생활의 변화에 효율적으로 적응할 수 있 도록 돕기 위하여 실시하는 교육프로그램을 말하지만 사실 그 범위와 종류가 매우 광범위하고 다양하다. 좁 게는 은퇴 직전에 실시하는 은퇴준비교육을 위한 교육 으로부터, 넓게는 전 생애에 걸친 인생의 설계를 돕는 교육까지를 포함하기 때문이다[6].

(2) 은퇴준비교육 프로그램으로는 은퇴의 의미, 노화 의 의미, 변화에 대한 인식, 개인적 가치발견, 삶에 대한 도전적인 태도, 은퇴 후의 계획 등 (3) 특히 퇴직자 교 육 요구 내용 중 정신·신체적 건강에 대한 요구는 자신 감을 고양시키는 법, 자기 존중감을 키우는 방법, 불안 
감을 극복하는 방법, 긍정적으로 사고하는 방법, 자책감 을 극복하는 방법, 스트레스 해소와 휴식을 즐기는 방 법, 무력감을 극복하는 방법에 대한 요구 등이 있다. (4) 전공과 타 전공으로 노년기를 준비한다. 이러한 은퇴 준비를 위한 교육은 그 학습 대상인 장년층, 노년층의 특성 및 욕구의 다양성, 교육 주체 기관의 다양성, 또 학 습 기간과 학습 내용 등의 다양성으로 인하여 그 형태 와 범위가 다양하게 나타날 수 있다[6].

\section{2 일반 노인교육의 프로그램}

노인교육 프로그램으로는 (1) 노화에 대한 준비와 적 응에 대한 내용, 즉 노인기의 특성과 노화의 과정에 대 한 지식을 획득함으로서 노인기에 대한 보다 구체적인 준비를 돕는다. (2) 노인교육의 목표체계로는 노인의 신체적, 경제적, 심리적, 사회적, 철학적 특성에 의하여 구성될 수 있다. 우선 철학적 차원에서 노인도 존엄한 인간적 존재로서 합당한 삶을 누릴 권리가 있다는 것을 강조한다. (3) 이러한 요인들을 고려해서 노인으로서 나이에 걸 맞는 일을 선택할 것이며 창조적인 삶을 영 위하도록 내면적 정신세계를 풍요롭게 함과 동시에 자 아실현을 행동하도록 교육 프로그램이 구성 돼야 할 것 이다[11]. (4) 노인교육은 그 자체로서 독특성과 전문성 을 지닌 독립분야로 다루어야하며 노인교육의 출발은 노인들과 관련자들의 요구로부터 출발하여야한다[14]. (5)특히 교육의 내용은 노인들의 경험 속에서 서로 연 결 통합과 새로운 분야의 관심을 충족시킬 수 있어야한 다. 구체적 내용으로는 노인의 생활교육과 취업 및 퇴 직 준비교육[4]이 필요하며 중고령자의 노인교육을 위 해서는 대학과 같은 전문적인 교육기관의 문호를 개방 해야한다.

\section{3 한국의 현실}

오늘의 한국 실정은 보건복지부의 지원을 받는 노인 교실에서 건전한 취미생활, 노인건강 유지, 소득보장, 기타 일상생활과 관련한 학습프로그램을 제공함을 목 적으로 하는 시설로 규정하고 있으나, 실제적으로는 노 인교육시설이 아닌 노인여가복지시설로 구분되어 있 다. 노인회에서 지원하는 노인대학과 노인학교 등으로
이들 기관은 교육 재정의 측면이나 교육전문성의 측면 에서 매우 취약함을 노정(露呈)하고 있다. 또한 대학의 평생교육원 프로그램 중 노인 학습자들을 대상으로 개 설된 프로그램은 다른 노인교육 기관에 비하여 상대적 으로 교육비가 비싼 편이어서 대부분의 많은 노인들이 참여하기에는 경제적인 어려움이 있다[4]. 결론적으로 오늘의 한국 실정은 아직도 미흡한 부분이 있다. 체계 적인 노인교육기능을 수행하기에는 많은 부족함이 있 고, 특히 중고령자가 교육을 받기에는 교육 프로그램이 빈약하다.

\section{4. 선진외국의 노인교육정책 사례}

다음은 선진외국의 노인교육정책 사례를 통하여 오 늘의 한국 노인교육 현실을 비교하고자 한다.

\section{1 미국의 노인교육정책}

미국의 노인교육정책은 연방정부의 교육부, 노동부, 복지보건부 등에서 담당하고 있다. 다양한 중앙행정부 서들이 서로 상호 협력관계 하에 있으며, 특히 보건복 지부가 주도적 역할을 하고 있다. 현재 노인복지 전달 체계로서 연방정부에는 노인청(Ad-ministration on Aging), 주정부에는 노인복지사무국(State Unit on Aging), 지방정부에는 노인지역사무소(Area Agency on Aging) 등의 전국적인 서비스 망을 구축하여 각 지 역주민의 특성과 욕구에 맞는 정책개발이나 실용적인 노인복지 서비스를 제공하고 있다[12].

(1) 미국의 퇴직 준비교육

미국에서는 기업뿐 아니라 대학과 지역 사회, 각종단 체 등이 적극적으로 나서서 퇴직을 맞이하기 전 중년에 서 퇴직(중고령자)을 하고 난 이후의 사회적응에 이르 기 까지를 지속적으로 지원, 관리하고 있다. 최근 미국 에서는 스스로 은퇴시기를 결정하고 은퇴 후의 삶을 재 창조하는 '신노인'들을 ' $2 \mathrm{Y} 2 \mathrm{R}$ 세대'(too young to retire-은퇴하기엔 너무 젊다.) 라고 부른다. 그들은 젊 어서부터 다양한 방식으로 노후를 준하고 계획함으로 서 경제적으로 여유 있고 신체적으로 건강을 유지하며 왕성한 사회활동을 누리고 있다. 특히 베이비붐 
(baby-boomer)이 노인이 되면서 이러한 경향은 급격 히 증가하고 있다. 각 대학은 노화 센터(Aging center) 나 노년학 센터(Gerontology center), 평생교육 센터 (Continuing Education Institute)등을 통하여 다양한 퇴직 전 교육 프로그램을 제공하고 있다[14].

(2) 다양해진 노인교육

이와 같이 미국은 노인교육을 성인교육의 일환으로 보아 고등교육의 기회를 확대하는 동시에, 노인들의 경 제적인 자립능력을 제고하는 정책방향을 제시함으로서 건강하게 일을 계속할 수 있는 능력을 가진 노인들은 연령에 관계없이 재취업 및 재배치의 기회를 제공받고 있을 뿐만 아니라 새로운 사회변화에 적응하기 위하여 재 적응 교육 및 현대화 교육에 무상으로나 보상을 받 으면서 참여할 수 있다. 오늘날 모든 대학에서의 노인 교육프로그램은 매우 다양하며, 각 대학에 개설되어 있 는 야간 교육 강좌, 농촌지역의 성인교육강좌, 그리고 텔레비전, 라디오, 컴퓨터 등을 이용한 현직교육강좌 등 은 노인교육의 일환으로 실시되고 있다. 특히, 이 가운 데 지역사회대학 (Community College)은 지역사회발 전에 기여하고 있으며, 주요 활동으로는 시설 이용과 지역봉사, 교육프로그램개발, 지역사회 지역 주민과의 상담, 대학교육 방송 등이며, 이런 교육활동은 지역사회 주민과의 노인교육과 가장 밀접한 관계를 맺고 있다.

\section{2 독일의 노인교육정책}

독일의 노년교육은 노년을 위한 준비교육, 제 3 의 시 기를 위한 교육, 시니어 교육, 50세 이상을 위한 학습, 노화 교육 등으로 매우 다양하게 불리어 왔다. 독일은 모든 사람이 맞는 노인기를 노인의 삶의 질 향상 과 긍 정적이며 활기 찬 인생주기로 만듦으로써 '새로운 노년' 으로 재탄생 시키고자 하는 의지에서 시작하였다[13].

특히, 노년교육은 노인의 다양한 교육적 욕구를 충족 시킬 뿐만 아니라 잠재력 개발까지 포함하는 매우 적극 적인 개념을 기초로 하고 있다. 그 결과 교육 내용도 매 우 포괄적 이여서 차세대에게 문화적인 지식을 전달하 여 주는 것으로부터, 민주시민으로써 정책 결정을 하는 데 적극적으로 참여하도록 시민을 교육하고, 세대 간 통합을 위한 교육으로 노인세대와 젊은 세대 사이의 갈
등을 해소하기 위하여 양방향의 의사소통이 이루어지 도록 하는 것을 포함하고 있다. 이러한 독일의 노년기 를 특화한 교육은 1970 년대의 정책수립기를 지나 1980 년대에는 노년교육의 다양성을 확보하였고, 1990년대 에는 노인이 갖고 있는 생산성과 창의성의 발현을 통한 자율적인 노년기를 만들며 지속적인 발전에 기초를 마 련하였다.

(1) 대학에서 실시되는 노인대학

독일의 대학들은 국민의 세금으로 운영되고 있어 학 비가 전혀 없다는 특성이 노년의 평생학습 발전에 큰 장점으로 작용하였다. 일반적으로 노인은 대학에서 개 설하고 있는 대부분의 정규과목을 청강할 수 있는 자격 을 갖고 있다. 이는 젊은 대학 학생들에게 폭 넓은 경험 을 할 수 있도록 하고, 노인세대 또는 학문적인 학습과 정에 참여함으로써 지속적인 상호 사회화를 가능케 하 는 효과를 갖고 있다. 대학에서는 노년교육의 전문성을 강조하여 노인대학(Senioren-Universitaet)이라 명명하 며 증가하는 노인의 학문적인 학습의 요구를 수용하려 고 애쓰고 있다. 노년교육은 대학교 마다 특성화되어 운영되며 교수법도 매우 다양하게 발전되고 있다.

\section{3 프랑스의 노인교육정책}

프랑스에서는 '노년(Old Age)'이라는 단어 대신 '제 3의 인생 (The Third Age)'이란 말을 사용하고 있다. 노년 혹은 노인이란 단어가 노년층의 역할을 축소하는 표현으로 받아들이고 있는 것이 사실이다[13]. 프랑스 는 각 지역에 다양한 '퇴직준비단체’를 구성하고 있으며 이 단체들은 교육 프로그램을 통하여 노년기에 대한 준 비를 권장하고 있다. 이러한 퇴직준비단체들의 회원은 각계각층의 전문직으로 구성되어 있으며, 퇴직을 앞둔 사람들에게 은퇴 후의 여가를 독립적이고 효율적으로 활용할 수 있도록 지원하고 있다. 인간의 삶은 아동기 와 사춘기, 직업에 의한 활동기, 직업에서 퇴직하는 시 기, 다른 것들에 의존하는 시기 등 네 단계로 구분할 수 있다. 특히 생의 마지막 단계인 의존시기의 위기를 최 소화할 수 있는 시기가 세 번째 단계인 퇴직하는 시기 이기 때문에 '제 3 의 인생'을 강조한다[13]. 지역 도시마 
다 전문직 은퇴자들로 구성된 은퇴자협회전국연합이 조직되어 있으며, 퇴직 전 준비교육과 자원봉사 등 다 양한 노년교육 프로그램을 자율적으로 운영하고 있다. 특히 퇴직 준비단체는 은퇴를 준비하고 있는 사람들을 대상으로 퇴직준비 단체에 대한 정보를 제공하고, 은퇴 자들의 법적권리와 의무, 사회보장제도 등을 안내하고 인터넷 교육, 노년학 관련 활동 등을 실시하고 있다. 각종 클럽의 운영, 재 취업알선을 위한 교육 프로그램, 세대통합교육 프로그램 등이 이루어지고 있다. 또한 지 역의 대학이 운영하고 있는 ‘은퇴 준비교육 프로그램'에 참여하고 있다. 가장 대표적인 프로그램은 상기한 제3 세대 대학(U3A)의 교육이다.

\section{4 일본의 노인교육정책}

(1) 노인지도자 양성 교육(고령자 인재활용 사업) 고령자 인재활용 사업(1978 83)이란 노인들의 잉여 에너지를 활용하자는 관점에서 종래의 레크리에이션 위주의 교육과는 달리 학습을 통하여 노인의 능력을 개 발하여 인재로서 적극적으로 활용하고자 하는 것이다. 즉, 사회교육을 담당하는 지도자를 양성함과 동시에 노 인의 사회참여를 촉진하기 위한 것으로, 노년교육이 단 순히 지식과 기능 습득에 머물지 않도록 그동안 연마한 학습의 성과를 사회교육현장에 활용하는데 초점을 두 고 있다. 지역에 지도자 양성강좌를 개설하여 일정기간 교육을 실시하고, 일정한 학점을 이수한 사람에게는 수 료증을 발행하여 인재뱅크에 등록하여 그들을 필요로 하는 곳에 지도자로 파견하는 것을 주요 내용으로 하고 있다.

(2) 장수학원개설 및 장수사회개발센터

다양한 노인층의 고차원적인 학습욕구에 체계적으로 부응하기 위하여 문부성은 1989 년부터 장수학원을 개 설하였다. 장수학원은 지역사회의 평생학습의 추진센 터, 대학과 전문대학교, 민간교육사업자 등과 적극적으 로 연계하여 노인에게 광역적이고 다양한 학습기회를 제공하고 수료자를 지역 활동의 지도자로 활용하는 것 을 주요 내용으로 하고 있다. 학점제를 도입하여 학습 의 질을 관리하고 개개인의 욕구에 맞는 교육을 선택할 수 있는 통신제를 운영하고 학습상 문제를 상담해주는
상담원을 배치하였다. 장수학원에서 2 년 이상을 학습하 고 일정 학점(30학점 이상)을 습득하면 수료 증서를 수 여하고 지역사회의 지도자로서 활약할 수 있도록 하였다.

(3) 퇴직 근로자를 위한 인생설계 교육

퇴직근로자와 노인이 전 생애를 의미 있게 보내도록 지원하기 위해 중·고령층 및 퇴직 전 근로자를 대상으 로 연수회를 개최하는 것이다. 교육 강좌는 '활력이 넘 치는 실용 시니어 학' 이라는 명칭으로 재단법인 미야 기(宮城) 재단이 주체가되어 2003년 8월부터2004년 3월 까지 총7회를 개최하였다. 교육 내용으로는 교양과 시 사 문제뿐만이 아니라 화제가 되고 있는 주제와 강사를 초빙하여 폭 넓은 지식을 습득하도록 하였다[13].

\section{III. 연구 설계}

\section{1. 자료의 수집과 분류}

본 연구에서는 노후준비에 노인교육이 미치는 영향 을 검증하기 위하여 서울시 노인복지회관을 이용하고 있는 노인들과 중 고령 직장인들과 중년 가정주부를 대 상으로 2007년 2월 11일부터 30일까지 20일간에 걸쳐서 집중적인 설문조사를 수행하였다. 320 부의 설문을 입수 하였으며, 불성실한 응답 15 부를 제외한 305 부의 설문 을 가지고 실증분석에 활용하였다.

\section{2. 자료의 분석방법}

본 연구의 자료 분석방법은

첫째, 각 영역에 대한 신뢰도 분석과 타당성 분석을 실시하였으며 조사대상자의 인구통계학적인 특성을 알 아보기 위하여 빈도분석(Frequency Analysis)을 실시 하였다.

둘째, 노인교육 필요성과 참여 욕구가 노후준비에 영 향을 미칠 것이다를 검증하기 위해 다중회귀분석을 실 시하였다.

셋째, 퇴직기대 수준은 노후준비에 영향을 미칠 것이 다를 검증하기 위해 다중회귀분석을 실시하였다.

넷째, 노인교육 필요성의 인식과 참여욕구 수준이 노 
후 준비에 미치는 영향에서 퇴직기대 수준은 매개 역할 을 할 것이다를 검증하기 위해 매개회귀분석을 실시하 였다.

다섯째, 응답자의 인구통계학적 특성에 따라 노인교 육의 필요성 인식, 퇴직 기대 수준, 노후 준비 수준은 차 이를 보일 것이다를 검증하기 위해 $\mathrm{t}$-검정과 일원변량 분석을 실시하였다.

또한, 본 연구의 가설은 다음과 같다.

첫째, 가설 1 : 노인교육의 필요성 인식과 노인교육참 여 욕구는 노후준비에 영향을 미칠 것이다. 둘째, 가설 2. 퇴직기대의 수준은 노후준비에 영향을 미칠 것이다. 셋째, 가설 3. 노인교육의 필요성 인식과 노인교육참여 의 욕구수준이 노후 준비에 미치는 영향에서 퇴직기대 수준은 매개 역할을 할 것이다. 넷째, 가설 4. 응답자의 인구통계학적 특성에 따라 노인교육 필요성의 인식과 노인교육참여욕구는 차이를 보일 것이다. 다섯째, 가설 5. 응답자의 인구통계학적 특성에 따라 퇴직 기대의 수 준은 차이를 보일 것이다. 여섯째, 가설 6. 응답자의 인 구통계학적 특성에 따라 노후 준비의 수준은 차이를 보 일 것이다.

\section{3. 변수의 조작적 정의}

\section{1 노후 준비}

노후준비를 측정하기 위하여 배문조(2006)가 '개인적 심리적 직업관련 변인이 은퇴기대와 은퇴준비에 미치 는 영향'의 연구에서 사용한 노후준비 척도를 인용하였 다. 노후준비 척도는 21 문항의 5점 리커트 척도로 구성 되어 있으며, 이들 변수들은 전혀 그렇지 않다를 1점, 매우 그렇다를 5 범으로 각각 구분하여 측정하였고 신 체적 준비, 심리적 준비, 경제적 준비의 3 가지 요인으로 나뉜다.

\section{2 노인교육 필요성과 교육 참여욕구}

노인교육의 필요성과 노인교육 참여욕구를 측정하기 위하여 배영희(2005)가 '중년층의 노후생활의식과 노후 사회교육참여에 관한 연구'에서 사용하였던 설문을 사 용하였다. 노인교육의 필요성은 2 문항, 노인교육참여 욕구는 총 5 문항으로 구성되어 있다. 이들 문항은 5 점
리커트 척도로 구성되어 있으며, 이들 변수들은 전혀 그렇지 않다를 1점, 매우 그렇다를 5점으로 각각 구분 하여 측정하였다.

\section{3 퇴직기대}

퇴직기대 척도는 총 30 개 문항으로서 이정의(2002)가 '교사 퇴직기대 유형, 결정요인, 퇴직준비교육과의 관련 성'에서 사용한 척도를 사용하였으며, '전혀 그렇지 않 다'에서 '매우 그렇다'까지의 5점 리거트(Likert )척도로 구성되어 있으며 이들 문항은 5점 리커트 척도로 구성 되어 있으며, 이들 변수들은 '전혀 그렇지 않다'를 1점, '매우 그렇다'를 5 범으로 각각 구분하여 측정하였으며 강요된 좌절, 새로운 출발, 휴식, 경력의 완성, 계속 기 대의 5 가지 요인으로 나뉜다.

\section{4 연구의 개념적 모형}

연구모형은 노인교육의 필요성과 노인교육참여욕구 가 퇴직기대와 노후준비에 미치는 영향을 살펴보기 위 해 설정하였다. 독립변수는 노인교육의 필요성과 참여 욕구이며, 종속변수는 노후준비로서 신체적 준비, 심리 적 준비, 경제적 준비를 포함하였다. 퇴직기대는 매개변 수로서 강요된 좌절, 새로운 출발, 휴식, 경력의 완성, 계속 기대를 포함하고 있으며 이들 변수들은 노인교육 의 필요성과 참여욕구가 노후준비에 미치는 영향요인 을 함께 고려하여 활용하였다.

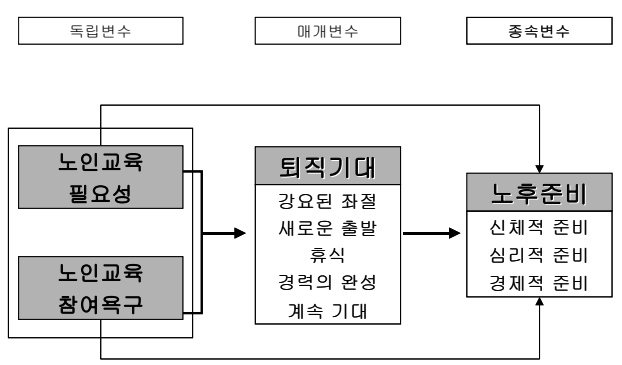

그림 1. 연구 모형

\section{IV. 연구결과 분석}

\section{1. 조사대상자의 일반적인 특성}

인구통계학적 사항에 대해 살펴보면 성별에 따라서 는 남자가 $42.6 \%$, 여자가 $57.4 \%$ 로 나타났고 연령에 따 라서는 61-64세가 21.6\%, 45-50세가 25.2\%, 51-55세가 
$23.3 \%$ 로 나타났다. 학력에 따라서는 대졸이 $57.7 \%$, 고 졸이 $26.6 \%$, 중졸이 $8.9 \%$ 로 나타났고 월소득에 따라서 는 300만원 이하가 $58.4 \%, 400$ 만원 이하가 $30.2 \%, 200$ 만원 이하가 $6.2 \%$ 로 나타났으며 현 직업에 따라서는 회사원이 $30.5 \%$, 자영업이 $29.5 \%$, 가정주부가 $22.0 \%$ 로 나타났다. 혼인상태에 따라서는 기혼이 $80.0 \%$, 사별이 $17.4 \%$, 미혼이 $2.6 \%$ 로 나타났다. 주거상태에 따라서는 자가가 $60.3 \%$, 전세가 $23.0 \%$, 월세가 $15.4 \%$ 로 나타났고 자녀수에 따라서는 2 명이 $41.0 \%, 1$ 명이 $25.6 \%, 3$ 명 이 상이 $25.2 \%$ 로 나타났으며 걱정거리에 따라서는 자녀문 제가 $36.7 \%$, 건강문제가 $27.5 \%$, 주택문제가 $23.0 \%$ 로 나 타났다.

\section{표 2. 인구통계학적 분석결과}

\begin{tabular}{|c|c|c|c|}
\hline \multicolumn{2}{|c|}{ 구 분 } & 빈도 & 백분율(\%) \\
\hline \multirow{2}{*}{ 성별 } & 남 & 130 & 42.6 \\
\hline & 여 & 175 & 57.4 \\
\hline \multirow{4}{*}{ 연령 } & 45-50세 & 77 & 25.2 \\
\hline & 51-55세 & 71 & 23.3 \\
\hline & 56-60세 & 66 & 21.6 \\
\hline & 61-64세 & 91 & 29.8 \\
\hline \multirow{4}{*}{ 학력 } & 중졸 & 27 & 8.9 \\
\hline & 고졸 & 81 & 26.6 \\
\hline & 대졸 & 176 & 57.7 \\
\hline & 대학원이상 & 21 & 6.9 \\
\hline \multirow{4}{*}{ 월소득 } & 200만원 이하 & 19 & 6.2 \\
\hline & 300 만원 이하 & 178 & 58.4 \\
\hline & 400만원 이하 & 92 & 30.2 \\
\hline & 400만원 이상 & 16 & 5.2 \\
\hline \multirow{6}{*}{ 현직업 } & 회사원 & 93 & 30.5 \\
\hline & 전문직 & 28 & 9.2 \\
\hline & 자영업 & 90 & 29.5 \\
\hline & 가정주부 & 67 & 22.0 \\
\hline & 공무원 & 9 & 3.0 \\
\hline & 기타 & 18 & 5.9 \\
\hline \multirow{3}{*}{ 혼인상태 } & 미혼 & 8 & 2.6 \\
\hline & 기혼 & 244 & 80.0 \\
\hline & 사별 & 53 & 17.4 \\
\hline \multirow{4}{*}{ 주거상태 } & 자가 & 184 & 60.3 \\
\hline & 전세 & 70 & 23.0 \\
\hline & 월세 & 47 & 15.4 \\
\hline & 기타 & 4 & 1.3 \\
\hline \multirow{5}{*}{ 자녀수 } & 1명 & 78 & 25.6 \\
\hline & 2명 & 125 & 41.0 \\
\hline & 3명 & 77 & 25.2 \\
\hline & 4명이상 & 8 & 2.6 \\
\hline & 없다 & 17 & 5.6 \\
\hline \multirow{4}{*}{ 걱정거리 } & 건강문제 & 84 & 27.5 \\
\hline & 주택문제 & 70 & 23.0 \\
\hline & 고독,외로움 & 30 & 9.8 \\
\hline & 자녀문제 & 112 & 36.7 \\
\hline
\end{tabular}

\begin{tabular}{c|c|c|c}
\hline & 없다 & 9 & 3.0 \\
\hline 합계 & 305 & 100.0 \\
\hline
\end{tabular}

\section{2. 신뢰성 분석}

신뢰도란 동일한 대상, 특성 또는 구성을 비교가능하 고 독자적인 측정으로 나타난 결과들이 어느 정도 유사 한가를 나타내는 것으로 의존가능성, 안전성, 일관성, 예측가능성, 정확성 등의 동의어로 사용된다. 즉, 신뢰 성이란 동일한 개념에 대하여 측정을 되풀이했을 때 동 일한 측정값을 얻을 가능성을 말한다.

신뢰성의 측정방법은 동일한 측정도구를 동일한 대 상에 시간을 달리하여 적용결과를 비교하는 검증-재검 증, 항목분할 측정치의 상관도, 내적일관성 등이 있다. 본 연구에 사용된 측정도구인 신뢰성은 Cronbach's 계 수를 이용하여 분석하였으며 일반적으로 0.6 이상이면 비교적 신뢰성이 높다고 한다. 구체적인 연구결과는 다 음 [표3]과 같다. 표에서와 같이 모든 요인에서 Cronbach's 계수가 0.6이상으로 나타나 신뢰성이 높게 나타났음을 알 수 있었다.

\section{표 3. 신뢰성 분석결과}

\begin{tabular}{|c|c|c|c|}
\hline 연구모형의 변수 & 하위 변수 & 문항수 & $\begin{array}{l}\text { Cronbach의 } \\
\text { 알파 }\end{array}$ \\
\hline \multirow{5}{*}{$\begin{array}{l}\text { I. 퇴직 기대 } \\
\text { (퇴직이후 삶에 } \\
\text { 대한 기대) }\end{array}$} & 강요된 좌절 & 11 & .717 \\
\hline & 새로운 출발 & 7 & .649 \\
\hline & 휴 식 & 5 & .697 \\
\hline & 경력의 완성 & 4 & .738 \\
\hline & 계속 기대 & 3 & .635 \\
\hline \multirow{3}{*}{ |I. 노후준비 } & 신체적 준비 & 6 & .806 \\
\hline & 심리적 준비 & 6 & .662 \\
\hline & 경제적 준비 & 9 & .738 \\
\hline \multirow{2}{*}{$\begin{array}{l}\text { III. 노인교육 필요성 } \\
\text { 과 참여욕구 }\end{array}$} & $\begin{array}{l}\text { 노인교육의 } \\
\text { 필요성 }\end{array}$ & 1 & .646 \\
\hline & $\begin{array}{l}\text { 노인교육의 } \\
\text { 참여성 }\end{array}$ & 5 & .826 \\
\hline
\end{tabular}

3. 노인교육의 필요성 인식과 참여 욕구 수준이 노 후준비에 미치는 영향

노인교육 필요성 인식과 노인교육 참여 욕구가 노후 준비에 미치는 영향에 대해 살펴보면 설명력은 $36.8 \%$ 를 설명하며 노인교육필요성 $(\beta=.379, \mathrm{p}<.001)$, 노인교 육참여욕구 $(\beta=.300, \mathrm{p}<.001)$ 가 영향을 미치는 것으로 
나타났다. 즉, 노인교육필요성과 노인교육참여욕구가 높아지면 노후준비에 대한 인식도 높아질 것이라고 예 측할 수 있었으며 영향력이 큰 순위는 노인교육필요성, 노인교육참여욕구 순으로 나타났다.

\section{표 4. 노인교육의 필요성 인식과 노인교육 참여 욕구가 은퇴} 준비에 미치는 영향

\begin{tabular}{c|c|c|c|c|c}
\hline 독립변수 & $\mathrm{B}$ & 표준오차 & $\beta$ & $\mathrm{t}$ & 유의도 \\
\hline (상수) & 2.100 & .087 & & 24.195 & .000 \\
\hline 노인교육필요성 & .180 & .027 & .379 & $6.665^{* * *}$ & .000 \\
\hline 노인교육참여욕구 & .158 & .030 & .300 & $5.271^{* * *}$ & .000 \\
\hline
\end{tabular}

주) 사례수 $=305, \mathrm{R}$-square $=.368, \mathrm{~F}=88.099, \mathrm{P}=.000{ }^{* * *} \mathrm{p}\langle .001$

\section{4. 퇴직기대 수준이 노후준비에 미치는 영향}

퇴직기대 수준이 노후준비에 미치는 영향에 대해 살 펴보면 설명력은 $42.1 \%$ 를 설명하며 새로운 출발 $(\beta$ $=.230, \mathrm{p}<.001)$, 경력완성 $(\beta=.316, \mathrm{p}<.001)$, 계속기대 $(\beta$ $=.218, \mathrm{p}<.001)$ 가 영향을 미치는 것으로 나타났다. 즉 새 로운 출발이 높아지고 경력완성이 커지며 계속기대가 높아지면 노후준비에 대한 인식도 높아질 것이라고 예 측할 수 있었으며 영향력이 큰 순위는 경력완성, 새로 운 출발 순으로 나타났다.

\section{표 5. 퇴직기대 수준이 노후준비에 미치는 영향}

\begin{tabular}{c|c|c|c|c|c}
\hline 독립변수 & $\mathrm{B}$ & 표준오차 & $\beta$ & $\mathrm{t}$ & 유의도 \\
\hline (상수) & 1.490 & .154 & & 9.666 & .000 \\
\hline 강요된좌절 & -.034 & .048 & -.036 & -.712 & .477 \\
\hline 새로운출발 & .194 & .052 & .230 & $3.753^{* * *}$ & .000 \\
\hline 휴식 & .046 & .035 & .070 & 1.327 & .185 \\
\hline 경력완성 & .182 & .030 & .316 & $6.009^{* * *}$ & .000 \\
\hline 계속기대 & .148 & .039 & .218 & $3.809^{* * *}$ & .000 \\
\hline
\end{tabular}

주) 사례수 $=305, \mathrm{R}$-square $=.421, \mathrm{~F}=43,401 \mathrm{P}=.000^{* * *} \mathrm{p}<.001$

5. 노인교육의 필요성 인식과 참여욕구의 수준이 노후준비에 미치는 영향에서 퇴직기대 수준의 매개 역할

노인교육의 필요성 인식과 참여욕구의 수준이 미치 는 영향에 있어서의 퇴직기대의 매개효과 정도를 검증
한 결과를 나타내고 있다.

퇴직기대를 종속변수로 한 회귀분석에서 노인교육의 필요성 인식은 통계적으로 유의한 독립변수( $\beta 1=.184$, $\mathrm{p}<.01)$ 인 것으로 나타나서 매개효과 검증을 위한 첫 번 째 조건을 충족시키고 있다. 또한 신체적 준비를 종속 변수로 한 회귀분석에서 노인교육의 필요성 인식은 긍 정적으로 유의한 영향( $\beta 2=.366, \mathrm{p}<.001)$ 을 미치는 것으 로 나타나 두 번째 조건을 충족시키는 것으로 나타났 다. 퇴직기대를 추가하여 독립변수로 투입하고, 신체적 준비를 종속변수로 한 Full 모형에서 퇴직기대는 신체 적 준비에 대하여 통계적으로 유의한 영향력( $\beta 4=.495$, $\mathrm{p}<.001)$ 을 갖는 것으로 나타나 세 번째 조건을 충족시 키고 있다. 따라서 노인교육의 필요성은 신체적 준비에 부분매개를 하는 것으로 나타났다. 이와 마찬가지로 심 리적 준비와 경제적 준비에 있어서도 노인교육의 필요 성은 각각 부분매개효과를 보임을 알 수 있었다.

노인교육참여욕구에 있어서는 1단계에서 유의한 독 립변수( $\beta 1=.145, \mathrm{p}<.01)$ 인 것으로 나타나서 매개효과 검증을 위한 첫 번째 조건을 충족시키고 있다. 또한 신 체적 준비를 종속변수로 한 회귀분석에서 노인교육의 참여욕구는 긍정적으로 유의한 영향 $(\beta 2=.171, \mathrm{p}<.01)$ 을 미치는 것으로 나타나 두 번째 조건을 충족시키는 것으 로 나타났다. 퇴직기대를 추가하여 독립변수로 투입하 고, 신체적 준비를 종속변수로 한 Full 모형에서 퇴직기 대는 신체적 준비에 대하여 통계적으로 유의한 영향력 $(\beta 4=.495, \mathrm{p}<.001)$ 을 갖는 것으로 나타나 세 번째 조건 을 충족시키고 있다. 따라서 중고령자에게 노인교육의 욕구는 신체적 준비에 완전매개를 하는 것으로 나타났 다. 또한, 심리적 준비와 경제적 준비에 있어서 노인교 육의 참여욕구는 각각 부분매개 효과를 가져왔음을 알 수 있었다.

\section{6. 응답자의 인구통계학적 특성에 따라 노인교육 필요성 인식차이}

\section{1 연구통계학적인 특성에 따른 노인교육의 필요성 인식의 차이}

연령에 따른 인식차이에 대해 살펴보면 노인교육의 
표 6. 노인교육의 필요성 인식과 참여욕구의 수준이 퇴직준비에 미치는 영향에서 퇴직기대의 매개효과

\begin{tabular}{|c|c|c|c|c|c|c|c|c|c|c|c|c|c|}
\hline 종속 & \multirow{2}{*}{ 구분 } & 독립변수 & \multicolumn{4}{|c|}{ 매개조건충족 } & 종속 & \multirow{2}{*}{ 구분 } & \multirow{2}{*}{$\begin{array}{c}\text { 독립변수 } \\
\text { 노인교육참여욕구 }\end{array}$} & \multicolumn{4}{|c|}{ 매개조건충족 } \\
\hline 변수 & & 노인교육필요성 & 1 & 2 & 3 & 4 & 변수 & & & 1 & 2 & 3 & 4 \\
\hline $\begin{array}{l}\text { 신체적 } \\
\text { 준비 }\end{array}$ & $\begin{array}{c}\text { 1단계 }(\beta 1) \\
\text { 2단계( } \beta 2) \\
\text { 3단계( } \beta 3 \text { :독립) } \\
\text { 3단계( } \beta 4 \text { :매개) }\end{array}$ & $\begin{array}{l}.184^{* * *}(.000) \\
.366^{* * *}(.000) \\
.180^{* *}(.003) \\
.495^{* * *}(.000)\end{array}$ & 0 & 0 & O & 0 & $\begin{array}{c}\text { 신체적 } \\
\text { 준비 }\end{array}$ & $\begin{array}{c}\text { 1단계( } \beta 1) \\
\text { 2단계( } \beta 2) \\
\text { 3단계( } \beta 3 \text { :독립) } \\
\text { 3단계( } \beta 4 \text { :매개) }\end{array}$ & $\begin{array}{c}.145^{* * *}(.000) \\
.171^{* *}(. .007) \\
.040(. .488) \\
.495^{* * *}(.000)\end{array}$ & 0 & $\mathrm{O}$ & $x$ & O \\
\hline $\begin{array}{l}\text { 심리적 } \\
\text { 준비 }\end{array}$ & $\begin{array}{c}\text { 1단계( } \beta 1) \\
\text { 2단계( } \beta 2) \\
\text { 3단계( } \beta 3 \text { :독립) } \\
\text { 3단계( } \beta 4 \text { :매개) }\end{array}$ & $\begin{array}{l}.376^{* * *}(.000) \\
.267^{* * *}(.000) \\
.194^{* *}(.005) \\
.194^{* *}(.002)\end{array}$ & 0 & 0 & 0 & 0 & $\begin{array}{c}\text { 심리적 } \\
\text { 준비 }\end{array}$ & $\begin{array}{c}\text { 1단계( } \beta 1) \\
\text { 2단계( } \beta 2) \\
\text { 3단계( } \beta 3 \text { :독립) } \\
\text { 3단계( } \beta 4 \text { :매개) }\end{array}$ & $\begin{array}{l}.265^{* * *}(.000) \\
.214^{* * *}(.001) \\
.163^{*}(.014) \\
.194^{* *}(.002)\end{array}$ & $\mathrm{O}$ & 0 & O & O \\
\hline $\begin{array}{l}\text { 경제적 } \\
\text { 준비 }\end{array}$ & $\begin{array}{c}\text { 1단계 }(\beta 1) \\
\text { 2단계 }(\beta 2) \\
3 \text { 단계( } \beta 3 \text { :독립) } \\
3 \text { 단계( } \beta 4 \text { :매개) }\end{array}$ & $\begin{array}{c}.138^{*}(.005) \\
.209^{* * *}(.001) \\
.133^{*}(.049) \\
.202^{* * *}(.001)\end{array}$ & 0 & 0 & 0 & 0 & $\begin{array}{l}\text { 경제적 } \\
\text { 준비 }\end{array}$ & $\begin{array}{c}\text { 1단계( } \beta 1) \\
\text { 2단계( } \beta 2) \\
\text { 3단계( } \beta 3 \text { :독립) } \\
3 \text { 단계( } \beta 4 \text { :매개) }\end{array}$ & $\begin{array}{l}.201^{* * *}(. .000) \\
.285^{* * *}(.000) \\
.231^{* * *}(.000) \\
.202^{* * *}(.001)\end{array}$ & $\mathrm{O}$ & 0 & 0 & O \\
\hline
\end{tabular}

${ }^{*} \mathrm{p}\left\langle .05,{ }^{* *} \mathrm{p}\left\langle .01,{ }^{* * *} \mathrm{p}<.001\right.\right.$

필요성에 따라서는 61-64세가 3.49점으로 높게 나타났 고 반면에 51-55세는 3.03점으로 상대적으로 낮게 나타 났으며 통계적으로도 유의미한 차이를 보였다. $(\mathrm{p}<.01)$ 학력에 따른 인식차이에 대해 살펴보면 노인교육의 필 요성에 따라서는 고졸이 3.56점으로 높게 나타났고 반 면에 중졸은 2.78점으로 낮게 나타났으며 통계적으로도 유의미한 차이를 보였다. $(\mathrm{p}<.01)$ 그 외 변수에 대해서 는 유의미한 차이를 보이지 않았다[표 8].

\section{2 연구통계학적인 특성에 따른 노인교육의 참여욕} 구 인식차이

성별 인식차이에 대해 살펴보면 노인교육참여욕구는 남자가 3.32점, 여자가 3.10점으로 남자가 여자보다 높 게 나타나서 통계적으로도 유의미한 차이를 보였 다. $(\mathrm{p}<.05)$ 즉 남자의 경우 여자보다 노인교육참여욕구 가 더 강하다는 것을 알 수 있었다. 노인교육참여욕구 에 따라서는 공무원이 4.07점, 가정주부가 3.30점으로 높게 나타났고 반면에 자영업이 3.06점, 회사원이 3.15 점으로 낮게 나타났으며 통계적으로도 유의미한 차이 를 보였다. $(\mathrm{p}<.05)$ 주거상태에 따른 인식차이에 대해 살펴보면 노인교육참여욕구에 따라서는 기타가 3.50점, 전세가 3.42점으로 높게 나타났으며 통계적으로도 유의 미한 차이를 보였다. $(\mathrm{p}<.05)$ 그외 변수에 대해서는 유 의미한 차이를 보이지 않았다[표 9].

\section{3 연구통계학적인 특성에 따른 퇴직기대의 인식차이} 연령에 대해서 퇴직기대는 45-50세가 3.30점으로 높 게 나타났고 반면에 51-55세는 2.99점으로 낮게 나타났 으며 통계적으로도 유의미한 차이를 보였다. $(\mathrm{p}<.001)$ 직업에 대해서는 공무원이 3.57점, 회사원이 3.26점으로 높게 나타났고 반면에 기타 3.01점, 가정주부 3.11점으 로 낮게 나타났으며 통계적으로도 유의미한 차이를 보 였다. $(\mathrm{p}<.05)$ 그 외 변수에 대해서는 유의미한 차이를 보이지 않았다[표 10].

\section{4 연구통계학적인 특성에 따른 노후준비의 인식의 차이}

연령에 대해서 노후준비에 따라서는 56-60세가 3.30 점으로 높게 나타났고 반면에 51-55세가 3.07점으로 낮 게 나타나서 통계적으로도 유의미한 차이를 보였 다.(p<.05) 그 외 변수에 대해서는 유의미한 차이를 보 이지 않았다[표 11]. 
표 8. 노인교육의 필요성 인식차이

\begin{tabular}{|c|c|c|c|c|c|c|}
\hline & & $\mathrm{N}$ & 평균 & 표준편차 & $t / F$ & 유의도 \\
\hline \multirow[t]{2}{*}{ 성별 } & 남 & 130 & 3.32 & 1.133 & \multirow[t]{2}{*}{-.401} & \multirow[t]{2}{*}{.689} \\
\hline & 여 & 175 & 3.37 & .891 & & \\
\hline \multirow[t]{4}{*}{ 연령 } & 45-50세 & 77 & 3.29 & 1.014 & \multirow{4}{*}{$\begin{array}{l}4.137 \\
* *\end{array}$} & \multirow[t]{4}{*}{.007} \\
\hline & 51-55세 & 71 & 3.03 & 1.048 & & \\
\hline & 56-60세 & 66 & 3.55 & .956 & & \\
\hline & 61-64세 & 91 & 3.49 & .926 & & \\
\hline \multirow[t]{4}{*}{ 학력 } & 중졸 & 27 & 2.78 & 1.163 & \multirow{4}{*}{$\begin{array}{c}5.200 \\
* *\end{array}$} & \multirow[t]{4}{*}{.002} \\
\hline & 고졸 & 81 & 3.56 & .880 & & \\
\hline & 대졸 & 176 & 3.38 & 1.015 & & \\
\hline & 대학원이상 & 21 & 3.00 & .758 & & \\
\hline \multirow[t]{6}{*}{ 직업 } & 회사원 & 93 & 3.32 & 1.031 & \multirow[t]{6}{*}{1.430} & \multirow[t]{6}{*}{.213} \\
\hline & 전문직 & 28 & 3.38 & .857 & & \\
\hline & 자영업 & 90 & 3.29 & .965 & & \\
\hline & 가정주부 & 67 & 3.51 & 1.013 & & \\
\hline & 공무원 & 9 & 3.72 & 1.176 & & \\
\hline & 기타 & 18 & 2.89 & 1.008 & & \\
\hline \multirow{3}{*}{$\begin{array}{l}\text { 혼인 } \\
\text { 상태 }\end{array}$} & 미혼 & 8 & 3.00 & .964 & \multirow[t]{3}{*}{1.262} & \multirow[t]{3}{*}{.285} \\
\hline & 기혼 & 244 & 3.32 & .957 & & \\
\hline & 사별 & 53 & 3.51 & 1.179 & & \\
\hline 주거 & 자가 & 184 & 3.31 & 1.072 & \multirow[t]{4}{*}{1.735} & \multirow[t]{4}{*}{.160} \\
\hline \multirow[t]{3}{*}{ 상태 } & 전세 & 70 & 3.55 & .881 & & \\
\hline & 월세 & 47 & 3.23 & .833 & & \\
\hline & 기타 & 4 & 2.75 & .957 & & \\
\hline
\end{tabular}

표 9. 노인교육의 참여욕구 인식차이

\begin{tabular}{|c|c|c|c|c|c|c|}
\hline & & $\mathrm{N}$ & 평균 & 표준편차 & $t / F$ & 유의도 \\
\hline \multirow{2}{*}{ 성별 } & 남 & 130 & 3.32 & 1.059 & \multirow{2}{*}{$\begin{array}{c}2.058 \\
*\end{array}$} & \multirow[t]{2}{*}{.040} \\
\hline & 여 & 175 & 3.10 & .748 & & \\
\hline \multirow[t]{4}{*}{ 연령 } & 45-50세 & 77 & 3.10 & 1.116 & \multirow[t]{4}{*}{1.046} & \multirow[t]{4}{*}{.372} \\
\hline & 51-55세 & 71 & 3.11 & .932 & & \\
\hline & 56-60세 & 66 & 3.27 & .725 & & \\
\hline & 61-64세 & 91 & 3.29 & .769 & & \\
\hline \multirow[t]{4}{*}{ 학력 } & 중졸 & 27 & 2.96 & 1.180 & \multirow[t]{4}{*}{1.521} & \multirow[t]{4}{*}{.209} \\
\hline & 고졸 & 81 & 3.27 & .805 & & \\
\hline & 대졸 & 176 & 3.23 & .893 & & \\
\hline & 대학원이상 & 21 & 2.93 & .842 & & \\
\hline \multirow[t]{6}{*}{ 직업 } & 회사원 & 93 & 3.15 & 1.071 & \multirow{6}{*}{$\begin{array}{c}2.413 \\
*\end{array}$} & \multirow[t]{6}{*}{.036} \\
\hline & 전문직 & 28 & 3.26 & .809 & & \\
\hline & 자영업 & 90 & 3.06 & .878 & & \\
\hline & 가정주부 & 67 & 3.30 & .623 & & \\
\hline & 공무원 & 9 & 4.07 & .825 & & \\
\hline & 기타 & 18 & 3.18 & .873 & & \\
\hline \multirow{3}{*}{$\begin{array}{l}\text { 혼인 } \\
\text { 상태 }\end{array}$} & 미혼 & 8 & 2.93 & .725 & \multirow[t]{3}{*}{1.660} & \multirow[t]{3}{*}{.192} \\
\hline & 기혼 & 244 & 3.16 & .850 & & \\
\hline & 사별 & 53 & 3.38 & 1.105 & & \\
\hline \multirow{4}{*}{$\begin{array}{l}\text { 주거 } \\
\text { 상태 }\end{array}$} & 자가 & 184 & 3.17 & .933 & \multirow{4}{*}{$\begin{array}{c}3.028 \\
*\end{array}$} & \multirow[t]{4}{*}{.030} \\
\hline & 전세 & 70 & 3.42 & .835 & & \\
\hline & 월세 & 47 & 2.93 & .810 & & \\
\hline & 기타 & 4 & 3.50 & .383 & & \\
\hline \multicolumn{5}{|c|}{${ }^{*} p<.05,{ }^{* *} p<.01,{ }^{* * *} p<.001$} & & \\
\hline
\end{tabular}

표 10. 퇴직기대의 인식차이

\begin{tabular}{|c|c|c|c|c|c|c|}
\hline & & $\mathrm{N}$ & 평균 & 표준편차 & $t / F$ & 유의도 \\
\hline \multirow[t]{2}{*}{ 성별 } & 남 & 130 & 3.19 & .568 & \multirow[t]{2}{*}{.440} & \multirow[t]{2}{*}{.660} \\
\hline & 여 & 175 & 3.17 & .423 & & \\
\hline \multirow[t]{4}{*}{ 연령 } & 45-50세 & 77 & 3.30 & .526 & \multirow{4}{*}{$\begin{array}{c}5.595 \\
* * *\end{array}$} & \multirow[t]{4}{*}{.001} \\
\hline & 51-55세 & 71 & 2.99 & .488 & & \\
\hline & 56-60세 & 66 & 3.24 & .488 & & \\
\hline & 61-64세 & 91 & 3.18 & .419 & & \\
\hline \multirow[t]{4}{*}{ 학력 } & 중졸 & 27 & 3.21 & .594 & \multirow[t]{4}{*}{2.006} & \multirow[t]{4}{*}{.113} \\
\hline & 고졸 & 81 & 3.29 & .491 & & \\
\hline & 대졸 & 176 & 3.13 & .478 & & \\
\hline & 대학원이상 & 21 & 3.13 & .382 & & \\
\hline \multirow[t]{6}{*}{ 직업 } & 회사원 & 93 & 3.26 & .539 & \multirow{6}{*}{$\begin{array}{c}2.606 \\
*\end{array}$} & \multirow[t]{6}{*}{.025} \\
\hline & 전문직 & 28 & 3.21 & .463 & & \\
\hline & 자영업 & 90 & 3.13 & .474 & & \\
\hline & 가정주부 & 67 & 3.11 & .367 & & \\
\hline & 공무원 & 9 & 3.57 & .473 & & \\
\hline & 기타 & 18 & 3.01 & .622 & & \\
\hline \multirow{3}{*}{$\begin{array}{l}\text { 혼인 } \\
\text { 상태 }\end{array}$} & 미혼 & 8 & 2.92 & .250 & \multirow[t]{3}{*}{1.194} & \multirow[t]{3}{*}{.305} \\
\hline & 기혼 & 244 & 3.18 & .487 & & \\
\hline & 사별 & 53 & 3.20 & .523 & & \\
\hline \multirow{4}{*}{$\begin{array}{l}\text { 주거 } \\
\text { 상태 }\end{array}$} & 자가 & 184 & 3.14 & .485 & \multirow[t]{4}{*}{2.506} & \multirow[t]{4}{*}{.059} \\
\hline & 전세 & 70 & 3.28 & .481 & & \\
\hline & 월세 & 47 & 3.13 & .505 & & \\
\hline & 기타 & 4 & 3.57 & .340 & & \\
\hline
\end{tabular}

표 11. 노후준비의 인식차이

\begin{tabular}{|c|c|c|c|c|c|c|}
\hline & & $\mathrm{N}$ & 평균 & 표준편차 & $t / F$ & 유의도 \\
\hline \multirow[t]{2}{*}{ 성별 } & 남 & 130 & 3.17 & .504 & \multirow[t]{2}{*}{-1.285} & \multirow[t]{2}{*}{.200} \\
\hline & 여 & 175 & 3.24 & .450 & & \\
\hline \multirow[t]{4}{*}{ 연령 } & 45-50세 & 77 & 77 & 3.19 & \multirow[t]{4}{*}{.468} & \multirow{4}{*}{$\begin{array}{c}3.103 \\
*\end{array}$} \\
\hline & 51-55세 & 71 & 71 & 3.07 & & \\
\hline & 56-60세 & 66 & 66 & 3.30 & & \\
\hline & 61-64세 & 91 & 91 & 3.26 & & \\
\hline \multirow[t]{4}{*}{ 학력 } & 중졸 & 27 & 3.04 & .534 & \multirow[t]{4}{*}{1.992} & \multirow[t]{4}{*}{.115} \\
\hline & 고졸 & 81 & 3.29 & .470 & & \\
\hline & 대졸 & 176 & 3.20 & .469 & & \\
\hline & 대학원이상 & 21 & 3.18 & .417 & & \\
\hline \multirow[t]{6}{*}{ 직업 } & 회사원 & 93 & 3.20 & .471 & \multirow[t]{6}{*}{2.057} & \multirow[t]{6}{*}{.071} \\
\hline & 전문직 & 28 & 3.23 & .471 & & \\
\hline & 자영업 & 90 & 3.13 & .452 & & \\
\hline & 가정주부 & 67 & 3.29 & .475 & & \\
\hline & 공무원 & 9 & 3.57 & .535 & & \\
\hline & 기타 & 18 & 3.12 & .507 & & \\
\hline \multirow{3}{*}{$\begin{array}{l}\text { 혼인 } \\
\text { 상태 }\end{array}$} & 미혼 & 8 & 3.07 & .430 & \multirow[t]{3}{*}{.368} & \multirow[t]{3}{*}{.692} \\
\hline & 기혼 & 244 & 3.21 & .468 & & \\
\hline & 사별 & 53 & 3.23 & .515 & & \\
\hline \multirow{4}{*}{$\begin{array}{l}\text { 주거 } \\
\text { 상태 }\end{array}$} & 자가 & 184 & 3.20 & .481 & \multirow[t]{4}{*}{.239} & \multirow[t]{4}{*}{.869} \\
\hline & 전세 & 70 & 3.25 & .432 & & \\
\hline & 월세 & 47 & 3.18 & .523 & & \\
\hline & 기타 & 4 & 3.24 & .374 & & \\
\hline
\end{tabular}




\section{V. 결론과 제언}

\section{1. 결론}

중고령자를 위한 노인준비교육이 그들의 이상적 노 인의 생활에 영향을 미칠 것 이라는 본연구의 목적은 사례연구를 통하여 다음과 같은 연구결과를 얻었다.

첫째, 노인교육의 필요성과 노인교육의 참여욕구가 노후준비에 긍정적으로 영향을 미치는 것으로 나타났 다. 둘째, 퇴직기대의 새로운 출발의 생각과, 경력완성 을 하고자하는 마음 그리고 계속기대 등은 노후준비에 동기부여와 매개효과로서 크게 영향을 미친다. 셋째, 퇴 직기대의 새로운 출발, 경력의 완성 그리고 계속기대는 노후준비를 위해서 노인교육의 필요성을 요구하게 되 었고, 또한 퇴직기대의 강요된 좌절과 새로운 출발의 욕구, 휴식, 그리고 경력의 완성의 기대가 신체적 노후 준비를 하는데 노인교육의 참여를 유도하였고 노후의 심리적 준비, 경제적 준비에 대해서는 부분적인 매개효 과를 보였다. 넷째, 인구통계학적인 특성에 따라 노인 교육의 필요성과 노인교육의 참여욕구 그리고 퇴직기 대와 노후준비는 성별, 연령, 직업, 학력에 따라 통계적 으로 유의미한 결과를 제시하고 있다.

본 사례연구에서 의미하는 시사점은 현재 노후준비 에 필요한 노인교육에 대해서 응답자의 인구통계학적 인 특성과 퇴직기대와 노후준비라는 관계차이를 정리 하였다는 점이 큰 의미라 하겠다. 또한, 향후 예비노인 인 중고령자들을 대상으로 하였다는 점이 현재 노년교 육의 부재와 정책상 제고의 효과를 가져 올 자료를 마 련하였다는 것이다. 더욱이 증가하는 노인의 문제를 위 한 노년교육의 활성화와 중고령자들의 미래를 위해서 는 전담행정부처의 신설과 이들의 재정적 지원마련이 필요하고, 노년교육을 전문으로 다루는 교육기관의 설 립을 강화할 필요성을 제기하고 있다. 또한, 노인은 대 상이 늙고 병들어 할 일이 없는 사회에서 소외당한 사 람이 아니라 축척된 지식과 기술의 경험을 최대한도로 활용하고 그들이 능동적인 주체자로 전환할 수 있다는 적극적인 의미로 해석하여 노년교육의 프로그램 전문 성과 다양성을 확보할 수 있도록 인식의 전환이 필요하 다는 결론을 얻었다.

\section{2. 제언}

첫째, 기업은 중고령층이 다양한 욕구에 따른 프로그 램을 제공할 수 있도록 프로그램 제공자는 현실에 맞게 구체적이고 실질적인 다양한 프로그램과 대상자들의 개인특성에 맞는 맞춤형 퇴직준비이자 노후준비 프로 그램을 준비해야 할 것이다.

특히 노인교육의 필요성과 참여욕구 수준이 중요한 영향요인이 됨에 있어서 다양한 노인교육 프로그램의 활성화를 위한 방안으로 우선 재취업 교육프로그램, 사 회참여 교육프로그램, 건강증진 교육프로그램. 문화취 미 교육프로그램 등이 있다.

둘째, 정부는 고령화 사회에서 고령사회로 가는 현재 의 시점에서 중년층이 퇴직 전에 노후생활을 계획성 있 게 준비할 수 있도록 노후준비교육의 일환인 퇴직준비 교육을 의무화하는데 제도적 장치를 마련해야 할 것이 다.

본 연구에서 의미하는 시사점은 대상자들을 향후 예 비노인인 중·고령자들을 대상으로 하였다는 점과 현 재 노후준비에 필요한 노인교육이라는 과제에 대해서 응답자의 인구통계학적인 특성과 퇴직기대와 노후준비 라는 관계차이를 정리하였다는 점 또한 현재 노년교육 의 부재와 정책상 제고효과를 가져올 계기를 마련하였 다는 것이 큰 의미다. 더욱이 노년교육의 활성화를 위 해서는 전담행정부처의 신설(예:노인청)과 이들의 재정 적 지원마련이 시급하고, 노년교육을 전문으로 다루는 교육기관의 설립을 강화할 필요성을 제기하고 있다. 또 한, 노인의 축척된 지식과 기술을 최대한도로 '인력뱅 크’를 활용하고 그들이 능동적인 주체자로 전환할 수 있다는 적극적인 의미로 해석하여 노년교육의 프로그 램을 전문성과 다양성을 확보할 수 있도록 인식의 전환 이 필요하다.

끝으로 본 연구결과를 통한 한계점을 지적하고 향후 연구를 위한 제언을 제시하면 다음과 같다.

첫째, 본 연구에서는 퇴직기대를 매개변수를 노후준 비를 종속변인으로 하여 연구를 실시하였기 때문에 다 른 연구결과와 비교하여 해석하는데 어려움이 있었다. 따라서 후속연구에서는 모든 사람들에게 일반화시킬 수 있는 퇴직기대와 노후준비 요인들을 추출하고, 이를 
객관적인 도구로 개발하여 이를 활용한 연구가 다양한 현장에서 이루어져 이들을 비교 연구하여 시사점을 밝 혀 나가야 할 것이다.

둘째, 본 연구에서는 한정된 집단의 의견 수렴으로 확대해석하기에는 무리가 있었다. 따라서 후속연구에 서는 다양한 지역과 계층을 포함하고 있는 노인들을 대 상으로 조사대상을 더 확대시켜야 할 것이다.

\section{참 고 문 헌}

[1] 교육인적자원부, 노인교육발전 5개년 계획, 2001. 12.

[2] 김길자, 평생교육관점에서의 노인교육프로그램연 구, 성심여자대학교 대학원 박사학위 논문, 2004.

[3] 김오차, 한국의 노인교육 정책에 관한 분석적 연 구, 안양대학교 대학원 박사학위논문, 2006(11).

[4] 김종길, 고령사회에서의 지방정부의 노인교육 활 성화 방안에 관한 연구, 충남대학교 박사학위논 문, 2005.

[5] 이시형, "에이징 파워", 2007

[6] 설은주, 고령화시대의 노인목회, 예영, 2005.

[7] 박재간, 21 세기 노인복지 정책 방향, 한국노인문 제연구소, 1999.

[8] 박재간, 홍미령, 노인교육 현황과 과제, 서울 ; 한 국 노인문제 연구소, 2000.

[9] 백은순, 성인기 여가의 특성과 여가교육에 관한 연구, 중앙대학교 대학원 박사학위논문, 1992.

[10] 통계청, 장래인구특별추계, 2005.

[11] 허춘광, '한국노인교육프로그램 평가에 관한 연 구' 광운대 대학원 박사논문 1997

[12] 홍문표, "노인복지청 설립을 위한 입법 공청회바람직한 노인정책 방안”, 2005.

[13] 한정란, 세계의 노인교육, 학지사, 2006.

[14] 한정란, 노인교육의 이해, 학지사, 2006.

[15] R. C. Atchley, "The Social Forces in Later Life.," Belmont. C. A. : Wadsworth Publishing Co., 1985.

[16] P .B. Baltes and M. M. Balter, "Successful
Aging,":Perspectives from the Behavioral Sciences. Cam : Cambridge University Press, 1990.

\section{저 자 소 개}

홍 석 태(Seok-Tae Hong)

정회원

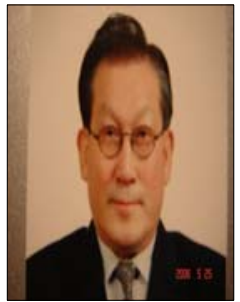

- 1985 : 연세대학교 경영대학원 경영학과

- 2007 : 호서대학교 벤처전문대 학원 박사 과정 수료 <관심분야> : 노인교육

양 해 술(Hae-Sool Yang)

정회원

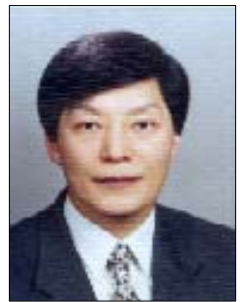

- 1991년 : 일본 오사카대학교정 보공학과 소프트웨어 공학 전공 (공학박사)

- 2001년 현재 : 한국정보처리 학회 부회장

- 1999년 현재 : 호서대학교 벤 처정보대학원 교수

<관심분야> : 소프트웨어공학(특히, $\mathrm{S} / \mathrm{W}$ 품질보증과 품질평가, 품질감리 및 컨설팅, $\mathrm{OOA} / \mathrm{OOD} / \mathrm{OOP}$, $\mathrm{SI}), \mathrm{S} / \mathrm{W}$ 프로젝트관리, 컴포넌트 기반 개발방법론 품질평가 